\title{
Analyzed Perceptions Of The Poor Peoples On Health Promotion Program In Poverty Reduction Policy Program At Health Sector (Pkbk) Puskesmas Onohazumba District Onohazumba South Nias District In 2021
}

\author{
Nirman Waruwu ${ }^{1}$, Emi Girsang ${ }^{2}$, Rapael Ginting ${ }^{3 *}$, Chrismis Novalinda Ginting ${ }^{4}$ \\ 1,2,3,4 Magister Of Public Health Program Study Medical, University Prima Indonesia , \\ Medan North Sumatera, Indonesia \\ *Correspondent Author: \\ Email: rapaelginting@unpri.ac.id
}

\begin{abstract}
.
The Health Sector Poverty Reduction Program (PKBK) is a tangible manifestation of the onohazumba district south nias government's concern for the poor by providing comprehensive health service assistance, including the nutritional health promotion program. Research Objectives: To get an overview of the perceptions of the poor towards the nutrition health promotion program. Research Methods, This research instrument have data collection by in-depth interviews and observation of promotional activities carried out by the puskesmas. Data analysis is done by content analysis. Triangulation of sources to stakeholders, NGOs/journalists, health workers, and Public health posyandu cadres. Results: There are different perceptions of the nutritional health promotion program from various characteristics of the respondents. Economic factors are an obstacle for a person to behave healthily and affect the utilization of health services. The lack of media, the limited use of methods, the material presented is very short and not in-depth, the frequency and adequacy of financing for nutritional health promotion programs affect the effectiveness of nutritional health promotion programs. Conclusion:
\end{abstract}

Keywords: Health Sector, Poor Peoples, Behavior Changes.

\section{INTRODUCTION}

Health improvement and development are directed at increasing awareness, willingness, and ability to live a healthy life for everyone so that the highest level of public health can be realized. Emphasis is given to the behavior and independence of the community as well as promotive and preventive efforts. Public health is one of the important things in realizing the degree of public health which has an impact on social and economic development. Improvement of various health problem factors will substantially reduce morbidity and mortality rates to improve the quality of life of healthy people, especially children in developing countries.Health Act No. 36 of 2009, providing health limits is a healthy condition both physically, mentally, spiritually, and socially that allows everyone to live socially and economically productive. According to the World Health Organization (WHO), health is a state of complete physical, mental and social well-being and not merely the absence of disease and disability. (Notoatmodjo, 2012).

Health is an investment to support economic development and has an important role in poverty reduction efforts. Health development must be seen as an investment to improve the quality of human resources by Law No. 36 of 2009 concerning health. According to WHO, globally the average national percentage of total government spending on health was $11.7 \%$ in 2014 . This measure shows the level of government spending on health in total spending on public sector operations in any one country and can be a part of the indicator. At least half of the world's population does not have full coverage of health care needs. Among those with access to needed services, many are experiencing undue financial hardship.

In 2010, it was estimated that 808 million people (11.7\%) of the world's population spent at least $10 \%$ of their household budget (total household expenditure or income) paying from their funds on health services. (Organization, 2019).Attachment to Presidential Decree Number 59 of 2017outlines the global goals, global goals, and national targets of the 2015-2019 RPJMN. The global goal consists of 17 goals, some of which are ending poverty in all its forms everywhere. Eliminate hunger, achieve food security and good nutrition, and promote sustainable agriculture. Ensuring healthy lives and promoting the well-being of people of all ages(Indonesia, 2017). The government, both central and regional, has made efforts to implement various policies and programs to reduce poverty, but it is still far from the main problem. Policies 
and programs implemented have not shown optimal results. There is still a gap between the plan and the achievement of goals because poverty reduction policies and programs are more oriented towards sectoral programs. Therefore we need an integrated, integrated, and synergized poverty alleviation strategy so that it can solve the problem completely because the problem of poverty is a cycle of poverty(Sukmaraga and Hayati, 2011).Health promotion is a form of education that seeks to make people behave in good health. The form of education, namely using persuasion, persuasion, appeal, invitation, providing information, or providing awareness. Health education or promotion is a form of intervention aimed at behavior so that behavior is formed for good health behavior. Health promotion seeks to make the behavior of individuals, groups, or communities have a positive influence on the maintenance and improvement of health. For these interventions or efforts to be effective, before intervention it is necessary to diagnose or analyze the behavior problem(Notoatmodjo, 2012).The results of Santi's research illustrate that economic factors are an obstacle for a person to behave healthily and affect the utilization of health services. The lack of media, the limited use of methods, the material presented is very brief and not in-depth, the frequency and adequacy of financing for nutritional health promotion programs affect the effectiveness of nutritional health promotion programs.

The community views that nutritional health promotion programs are still limited to providing knowledge. Behavior change is hindered by financial inadequacy. In general, the success of nutritional health promotion programs is influenced by the adequacy of funds, availability of media, use of methods, promotional materials, frequency of promotions, access to promotional services, limited promotion targets, and community participation. (Sohot, 2007) Research conducted by Haris Fariadi shows that most of the parents of children under five do not know that they are still in a condition of inappropriate parenting, both in terms of parenting and feeding, as well as parenting patterns for health care and sanitation hygiene as well as a less supportive home environment, while concern for poor families towards health is still very low. low, the lack of poor families in utilizing existing health facilities. The perception of poor families towards assistance in dealing with nutritional problems is positive. They think that the assistance is very useful in supporting the family's economy and can also improve the nutritional status of their children, and with the assistance activities, they feel the benefits because they feel that they are cared for every month to control their children's health.(Fariadi, Kanto and Mardiyono, 2016). The Onohazumba Health Center is a community health service center located in the Onohazumba sub-district, which has a function as an organizer of public health efforts. The results of the initial survey conducted by researchers by conducting interviews with several respondents, namely to 1 health worker at the Onohazumba Health Center who explained that the health promotion program had been carried out to all levels of society in the working area of the puskesmas with various topics of discussion ranging from maternal, infant and toddler health, children preschool, youth, and elderly health. As well as interviews conducted with 3 mothers, it was found that from the three respondents stated that health promotion had been carried out by health workers,

\section{LITERATURE REVIEW}

\subsection{Review of Past Research}

Rusni Djafar. Poverty Reduction Based on Community Empowerment in Pohuwato Regency (2019). This research focuses on poverty alleviation problems based on empowerment through sustainable assistance, facilitation, and promotion activities. This approach to empowerment in poverty alleviation requires the synergy of stakeholders, particularly the role of local governments and target communities. The results of this study also indicate that assistance activities through training and skills for the target community as beneficiaries are aimed at enabling the target community to have the ability to manage aid so that the community can live independently. It was also found that the poor have not been fully involved as program targets from the planning, implementation to evaluation processes, so that the reduction in poverty rates slowed down. Basically,(Djafar and Sune, 2019).Haris Faradi. Perceptions of the Poor towards Health Services in the Nutrition Sector (Case Study in the Sidotopo Public Health Center, North Surabaya) (2016) The results showed that most of the parents of children under five did not know that they were still in a condition of inappropriate parenting, both in feeding parenting patterns, as well as health care and sanitation 
hygiene care practices and a less supportive home environment, while for poor families' concern for health is still very low, the lack of poor families in utilizing existing health facilities.

The perception of poor families towards assistance in dealing with nutritional problems is positive. They think that the assistance is very useful in supporting the family's economy and can also improve the nutritional status of their children, and with the assistance activities they feel the benefits because they feel that they are cared for every month to control their children's health.(Fariadi, Kanto and Mardiyono, 2016). Ardiana Priharwanti. Health Promotion Strategy in Efforts to Reduce Maternal Mortality Rate (MMR) in Pekalongan City. (2017) Based on the results of the research conducted, the health promotion strategy to reduce MMR in Pekalongan City is through the strategy; Advocacy is to strengthen the policy to reduce MMR in the city of Pekalongan through regional institutions. every citizen that AKI is a common problem, not a problem from the health department or an individual problem. optimizing the dissemination of information through social media (social media) to support the acceleration and dissemination of information regarding AKI, monitoring, coordination between cadres, posyandu, traditional stakeholders, religious leaders and health workers. In addition, the integration of this technology is sought to increase the speed of referral actions.

\subsection{Health Sector Poverty Reduction Policy Program (PKBK)}

Indonesia's major development agenda is contained in the National Medium Term Development Plan (RPJMN) 2010-2014 which is then translated into the annual Government Work Plan (RKP). The theme of the 2010 RKP is "Recovery of the National Economy and Maintenance of People's Welfare, while the theme of the 2011 RKP is "Accelerating Economic Growth with Equity Supported by Consolidated Governance and Synergy of the Regional Center". The 2010-2014 RPJMN has also set targets for economic development and improving people's welfare, including (1) Economic growth, with a projection of $7.0-7.7 \%$ in 2014 ; (2) Reducing the unemployment rate, with a target of $5-6 \%$ by the end of 2014; and (3) Poverty reduction, with a target of $8-10 \%$ by the end of 2014(RI, 2011). In this regard, the government has set three strategic paths for development, namely: (1) Pro-Growth, to increase and accelerate economic growth through investment, so that an improvement in the investment climate is needed, through increasing the quality of government spending, through exports, and increasing consumption; (2) Pro-Job (pro-job), so that economic growth can create the widest possible employment opportunities by emphasizing labor-intensive investment; (3) ProPoor (pro-poor), so that economic growth can reduce the number of poor people as much as possible by improving the social protection system, increasing access to basic services, and empowering the community.

The development carried out is intended to create the widest possible employment opportunities and reduce the number of poor people as quickly as possible by involving the whole community (inclusive growth). To improve coordination of poverty reduction, the government issued Presidential Regulation Number 15 of 2010, concerning the Acceleration of Poverty Reduction, which is a refinement of Presidential Regulation Number 13 of 2009 concerning Poverty Reduction Coordination. The Presidential Decree is mandated to form a National Team for the Acceleration of Poverty Reduction (TNP2K) at the central level whose membership consists of elements of the government, community, the business community, and other stakeholders. Meanwhile, in provinces and regencies/cities, Provincial and Regency/Municipal Poverty Reduction Coordination Teams (TKPK) are formed. (RI, 2011)

\section{METHODS}

The approach used in this study is a qualitative approach. Qualitative research is research that does not use calculations. (Lexi J, Moleong. 2002) or termed scientific research that emphasizes the natural character of data sources. Meanwhile, according to Sukmadinata, qualitative research is a research aimed at describing and analyzing phenomena, events, social activities, attitudes, beliefs, perceptions, thoughts of people individually and in groups.(Syaodih Sukmadinata, 2007). This type of research is descriptive qualitative research, namely research methods carried out with the main aim of making a description or description of a situation objectively, with a semi-structured interview method, which is a type of interview that is included in the in-depth interview category which is recorded using a smartphone. more free when compared to structured interviews (Raco, 2018).This qualitative research uses a case study approach, namely 
the type of approach used to investigate and understand an event or problem that has occurred by collecting various kinds of information which is then processed to obtain a solution so that the problems revealed can be resolved.Observation is the systematic observation and recording of the phenomena being investigated. According to Mardalis, the observation method is the result of the soul's active and attentive actions to realize the existence of a certain desired stimulus, or a deliberate and systematic study of social conditions or phenomena and psychological symptoms by observing and recording.

The data that has been collected is processed and analyzed descriptively-qualitatively, namely presenting the data in detail and carrying out theoretical interpretations so that an adequate description and conclusion can be obtained.(Rachmawati, 2017). Interviews are used as a data collection technique if the researcher will carry out a preliminary study to find problems that must be investigated, and also the researcher wants to know things from respondents who are more in-depth and the number of respondents is small.(Sugiyono, 2017). The interview method or interview is a method that is carried out by conducting communication with data sources through dialogue (question and answer) orally, either directly or indirectly. Lexy J Moleong defines an interview as a conversation with a specific purpose. The conversation was carried out by two parties, namely the interviewer (interviewer) who asked the question and the interviewee (interviewer) who gave the answer to the question.(Moleong, 2002). Written goods documents. In using the documentation method, the researcher investigates written objects such as books, magazines, documents, regulations, and so on. In a broader sense, documents are not only verbal, but can be in the form of relics such as inscriptions and symbols.(Arikunto, 2010).

\section{ANALYZE AND RESULT.}

\subsection{Based Data.}

UPTD Onohazumba Health Center Onohazumba Subdistrict, South Nias Regency This is a Public Health Center owned by the South Nias Regency Government which acts as the leading spearhead in implementing health development, especially in Onohazumba District. The boundaries of the Onohazumba Health Center area, Onohazumba District, are:

\section{North : bordering West Nias Regency}

2. East : $\quad$ : bordered by Hunura and Districts Lolomatua

3. South side : bordering the District of Lolowau and Hilimegai

4. West Side : bordering Hilisalawa'ahe . District

South Nias Regency's poverty rate decreased by 0.20 points, from 16.65 percent in September 2018 to 16.45 percent in March 2019. This poverty rate is equivalent to 52,510 people in September 2018, or a decrease of around 190 people. When compared with the achievements of North Sumatra Province in 2019, the percentage of poverty in South Nias Regency is still very high compared to North Sumatra Province.The key informants in this study were 5 housewives with middle to lower economic status in the working area of UPTD Puskesmas Onohazumba, Onohazumba District.

In the table below is a description of the characteristics of the main informants in this study, which are as follows:

Table 1. Main Informant Characteristics

\begin{tabular}{lllll}
\hline Informant & Gender & Age & Education & Work \\
\hline 1 & Woman & 40 years & SD & Farmers/IRT \\
2 & Woman & 45 years old & SD & Farmers/IRT \\
3 & Woman & 43 years old & SD & Farmers/IRT \\
4 & Woman & 42 years old & SD & Farmers/IRT \\
5 & Woman & 36 years old & SD & Farmers/IRT \\
\hline
\end{tabular}

\subsection{Affective Aspect}

The affective aspect is the aspect that concerns the emotions of the individual. Individuals in perceiving something can be through affective aspects that are based on the individual's emotions, this can arise because of the moral and ethical education obtained since childhood, ethical and moral education is what ultimately becomes the basis of the individual in looking at something that is happening around him. 
Emotions are judgmental reactions (positive or negative) that are complex in themselves. This definition illustrates that emotion begins with a stimulus, both from outside and from within the individual. Individuals then interpret the perception of the stimulus as positive (fun, interesting) or negative (fearful, want to avoid).(Sarlito, 2012). The affective indicator here is a feeling concerning the subjective emotional aspect of the individual towards the object of perception, namely public policy. In this study, affective indicators relate to the community's point of view on whether or not they agree or disagree, such as public opinion and responses about poverty reduction policies in the health sector. Here are the main informants' answers:

Tables 2. Key Public opinion

\begin{tabular}{ll}
\hline Key Informants & Answer \\
\hline 1 & Yes, it's good, and I feel happy with this program and we feel \\
& very helpful \\
2 & That's great, boo, so we are helped for my health problems and \\
& that of my family \\
3 & Nice ma'am, and I feel happy with this help \\
4 & Good and we feel very helpful \\
5 & Oh, I'm so happy, we feel very helpful \\
\hline
\end{tabular}

This is supported by statements from additional informants who explained that this program was given to the poor. Here are additional informants' answers:

Tables 3. Additional Informants Data

\begin{tabular}{ll}
\hline Additional Informants & Answer \\
\hline 1 & Yes, they are very happy and even happy because they get free \\
& health assistance \\
& People feel happy for sure because they don't need to hesitate or \\
& even be afraid to seek treatment if one of their families is sick and \\
doesn't think about the cost of treatment.
\end{tabular}

\subsection{Conative Aspect}

The conative aspect is a component related to the tendency to act on the attitude object. This component shows the intensity of the attitude that shows the size of the tendency of a person's reaction or response to an object.The conative indicator here contains a tendency or tendency to act or react to a perceived object, namely public policy in a certain way. The conative aspect shows how the community's behavior towards poverty reduction programs in terms of health is realized by taking actions that can be in the form of responses and criticisms of achieving results that are not in accordance with community goals and expectations.In this study, conative indicators that relate to real actions from the poor regarding poverty reduction programs in the health sector are in the form of participation in this program how mothers use assistance. Here are the main informants' answers:

Tables 4. Receive assistance in poverty reduction programs in the health sector.

Here are the main informants' answers:

\begin{tabular}{ll}
\hline Key Informants & Answer \\
\hline 1 & I definitely use it because it really helps me and my family \\
2 & Yes, I will use it \\
3 & I will use it for me and my family \\
4 & As I said earlier, I will use this for myself and my family \\
5 & I use it and it is very useful for medical purposes if someone is \\
& sick \\
\hline
\end{tabular}

\subsection{Based on Cognitive Aspect}

Cognitive components are components related to knowledge, views, beliefs, namely things related to how people perceive the object of attitude. The conative aspect of the research is the knowledge of the poor. Knowledge is an important domain for the formation of one's actions (overt behavior), behavior based on knowledge will be more lasting than behavior that is not based on knowledge. So that knowledge has a very big role in shaping a behavior (Notoadmodjo). Based on the results of research observations, it shows that the 
statement of the main information about knowledge of the Poverty Reduction Policy Program in the Health Sector is as follows:

"Do not know and do not understand the Poverty Reduction Policy Program in the health sector before being given counseling and information about the program"(all key informants).

The answers of all key informants are in line with statements from additional informants, as follows:

"They don't know and don't understand before being given an explanation about the program" (1 additional informant) (Head of Hamlet).

"People don't know the purpose of this program at all" (2 additional informants) (Tenkes/Pj. Desa)

Based on the results of observations, it can be seen that public knowledge in poverty reduction policy programs in the health sector is in the poor category. The results of this study are in line with research conducted by Noviansyah (2006). The knowledge that the community has about insurance or health insurance shows a significant relationship with the public's perception of PJKMM. Insurance or health insurance in this case for the poor aims to increase access to health services, but this goal is often not achieved due to a lack of understanding and knowledge of the community about insurance or health insurance. There is a gap between understanding or knowledge about insurance, especially the procedures for accessing services and the types of services obtained,

Based on the results of the interview, it can be seen that the economy of the community is classified as low which affects the health of the community itself which cannot afford health financing. These results are in line with research conducted by M. Pinem (2016), the socioeconomic status of each individual is different from one another. The existence of differences in socioeconomic status often causes differences and inequalities of people in judging something, meaning that the socioeconomic level determines a person's attitude towards certain things. On the one hand, social conditions such as work and education greatly determine the level of income or family income, on the other hand, good economic conditions can provide good social status as well. It can be concluded that what is meant by socio-economic status is the condition of a society which is reflected in its ability to carry out economic activities to meet the needs of daily life. (Effect of education and socio-economic status of household heads on environmental health).

\subsection{Based on Conative Aspect}

The conative aspect is a component related to the tendency to act on the object of attitude. This component shows the intensity of the attitude that shows the size of the tendency of a person's reaction or response to an object. Intention is determined by subjective attitudes and norms. The first component refers to attitudes towards behavior. This attitude is the result of consideration of the advantages and disadvantages of the behavior (outcome of the behavior). Besides, it is also a consideration of the importance of the consequences that will occur for individuals (evaluation regarding the outcome). On the other hand, the subjective or social norm component refers to one's beliefs about how and what people think is important and one's motivation to follow those thoughts (Priyoto, 2003). The conative indicator here contains a tendency or tendency to act or react to a perceived object, namely public policy in a certain way. The conative aspect shows how the community's behavior towards poverty reduction programs in terms of health is realized by taking actions that can be in the form of responses and criticisms of achieving results that are not in accordance with community goals and expectations.

\subsection{Research Weaknesses}

This research was conducted inseparable from the limitations possessed by the researcher, namely as follows:

1.The interview was not held in a special place, so the concentration was not so focused

2.The study design is flexible with unpredictable steps and outcomes.

3.PeThis research is a beginner qualitative research, so there are still many shortcomings in this research because it was carried out with a short research time so that it could not describe more concrete results. This was overcome by researchers in consultation with supervisors and consultations with community leaders and local health workers who knew the circumstances and conditions of the community in this study, then researchers corrected errors so that writing became better 


\section{CONCLUSION}

The conclusions that can be drawn from this research are as follows:

1. From the cognitive aspect, it can be said that the knowledge aspect is lacking where the understanding of the poor in the working area of the UPTD Puskesmas Onohazumba Subdistrict, Onohazumba Subdistrict, thinks they do not know the purpose of the poverty reduction program in the health sector, while from the experience aspect the poor have no experience or have ever felt from this program.

2. From the affective aspect, from the attitude aspect, it can be said that the response of the poor is quite positive towards health promotion programs in poverty reduction in the health sector. Meanwhile, from the aspect of community response, it is said to be quite good towards this program where the community is quite enthusiastic about listening to the counseling given by health workers related to this program.

3. From the conative aspect, from the action aspect, it can be said that the poor have a high motivation to be able to participate in poverty reduction programs in the health sector where the poor feel cared for and help them with health financing problems for free.

\section{REFERENCES.}

[1] Arikunto, S. (2010) 'Research Procedures A Practical Approach. 2010', Jakarta: Rineka Cipta.

[2] Bimo, W. (2000) 'Social Psychology as an Introduction'. Yogyakarta. Andi Offset.

[3] Djaelani, AR (2013) 'Data Collection Techniques in Qualitative Research', Pawiyatan, 20(1).

[4] Djafar, R. and Sune, U. (2019) 'Poverty Reduction Based on Community Empowerment in Pohuwato Regency', Madani Journal of Politics and Sociology, 11(3), pp. 246-270.

[5] Dunia, B. (2007) 'A New Era in Poverty Reduction in Indonesia', Translation) Publisher: The World Bank.

[6] Efendi, M. (2019) 'Health promotion behavior of the assisted members of the Family Hope Program (PKH) in Penanggungan Village, Malang City'. Maulana Malik Ibrahim State Islamic University.

[7] Fariadi, H., Kanto, S. and Mardiyono, M. (2016) 'Perceptions of the Poor towards Health Services in the Nutrition Sector (Case Study in the Sidotopo Health Center Area, North Surabaya)', Pamator Journal, 9(2).

[8] Iman, M. (2015) 'Guidelines for the Preparation of Scientific Papers in the Health Sector', Medan: Pioneer Media Citabina.

[9] Indonesia, R. (2017) 'Presidential Regulation No. 59 of 2017 concerning Implementation of Achieving Sustainable Development Goals'.

[10] Mardiyah, S. and Ns, MK (2020) 'Teaching Module for Health Promotion'.

[11] Moleong, LJ (2002) 'Qualitative Research Methods, Bandung: PT Pemuda Rosdakarya, 2007'. Milles.

[12] Mubarak, WI (2011) Health promotion for midwifery. Salemba Medika Publisher.

[13] Notoatmodjo, S. (2012) Health promotion and health behavior, Jakarta: rineka copyright.

[14] Nurmala, I. (2020) Health Promotion. Airlangga University Press.

[15] Organization, WH (2017) State of health inequality: Indonesia. World Health Organization.

[16] Organization, WH (2019) 'World health statistics 2019: monitoring health for the SDGs, sustainable development goals'. World Health Organization.

[17] Priharwanti, A., Fitriani, E. and Baiti, N. (2017) 'Health Promotion Strategy in Efforts to Reduce Maternal Mortality Rate (MMR) in Pekalongan City', Journal of Research and Development of Pekalongan City, 13.

[18] Putra, MAP (2016) 'Analysis of the Public Service Bureaucracy at the Makassar City BPJS Office'.

[19] Rachmawati, T. (2017) 'Data Collection Methods in Qualitative Research', UNPAR Press. Bandung.

[20] Raco, J. (2018) 'Qualitative research methods: types, characteristics and advantages'. OSF Preprints.

[21] Restuastuti, T. et al. (2017) 'Analysis of Community Empowerment in the Health Sector', Malay Journal of Health, 1(1), pp. 14-19.

[22] RI, K. (2017) 'Indonesian Health Profile', Ministry of Health RI.

[23] RI, KK (2011) 'Poverty Reduction Program United Indonesia Cabinet II'. Jakarta: Ministry of Communication and Informatics RI.

[24] Rodiah, S., Budiono, A. and Rohman, AS (2018) 'Model of information dissemination of rural public health communication in West Bandung Regency', Journal of Communication Studies, 6(2), pp. 175-190.

[25] Sarlito, SW (2012) 'Adolescent Psychology (revised edition)', Jakarta: PT. King Grafindo Persada.

[26] Slameto, I. (2010) Learning and Influencing Factors, Jakarta: Rineka Cipta.

[27] Sohot, S. (2007) 'Perceptions of the poor towards the Health and Nutrition Promotion Program in the Health Sector Poverty Reduction Policy Program (PKBK) of Balikpapan City'. Gadjah Mada University. 
[28] Sugiyono (2017) Educational research methods: (quantitative, qualitative and R \& D approaches). Alphabet.

[29] Sukmaraga, P. and Hayati, B. (2011) 'Analysis of the Influence of Human Development Index, GRDP per capita, and the Number of Unemployment on the Number of Poor Population in Central Java Province'. Diponegoro University.

[30] Sumartono, S. and Astuti, H. (2018) 'Use of Posters as Health Communication Media', Communicology: Scientific Journal of Communication Studies, 15(1).

[31] Susilowati, D. (2016) Health promotion. Ministry of Health of the Republic of Indonesia.

[32] Syaodih Sukmadinata, N. (2007) Educational research methods, Bandung: Youth Rosda Karya.

[33] North, DPS (2017) '2016 North Sumatra Health Profile', Medan North Sumatra Health Service.

[34] Widiyaningsih, D. and Suharyanta, D. (2020) Health Promotion and Advocacy. Depublish. 